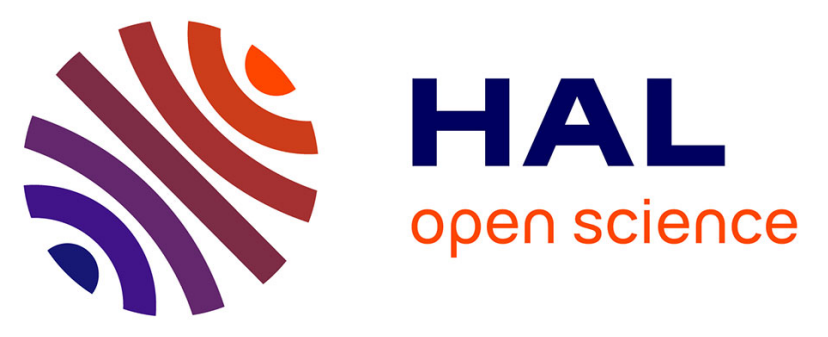

\title{
Pressurized intra-peritoneal aerosol chemotherapy (PIPAC): increased intraperitoneal pressure does not affect distribution patterns but leads to deeper penetration depth of doxorubicin in a sheep model
}

Myriam Mimouni, Christophe Richard, Pierre Adenot, Martine Letheule, Anne Couturier-Tarrade, Olivier Sandra, Michèle Dahirel, Thomas Lilin, Benoit Lecuelle, Valerie Gelin, et al.

\section{- To cite this version:}

Myriam Mimouni, Christophe Richard, Pierre Adenot, Martine Letheule, Anne Couturier-Tarrade, et al.. Pressurized intra-peritoneal aerosol chemotherapy (PIPAC): increased intraperitoneal pressure does not affect distribution patterns but leads to deeper penetration depth of doxorubicin in a sheep model. BMC Cancer, 2021, 21, pp.461. 10.1186/s12885-021-07955-w . hal-03211408

\author{
HAL Id: hal-03211408 \\ https://hal.science/hal-03211408
}

Submitted on 28 Apr 2021

HAL is a multi-disciplinary open access archive for the deposit and dissemination of scientific research documents, whether they are published or not. The documents may come from teaching and research institutions in France or abroad, or from public or private research centers.
L'archive ouverte pluridisciplinaire HAL, est destinée au dépôt et à la diffusion de documents scientifiques de niveau recherche, publiés ou non, émanant des établissements d'enseignement et de recherche français ou étrangers, des laboratoires publics ou privés.

\section{(ㄷ)(i)}

Distributed under a Creative Commons Attribution| 4.0 International License 


\title{
Pressurized intra-peritoneal aerosol chemotherapy (PIPAC): increased
} intraperitoneal pressure does not affect distribution patterns but leads to deeper penetration depth of doxorubicin in a sheep model

Myriam Mimouni ${ }^{1,2,3^{*}}$, Christophe Richard ${ }^{1,2}$, Pierre Adenot ${ }^{1,2}$, Martine Letheule ${ }^{1,2}$, Anne Tarrade ${ }^{1,2}$, Olivier Sandra ${ }^{1,2}$, Michèle Dahirel ${ }^{1,2}$, Thomas Lilin ${ }^{4}$, Benoit Lecuelle ${ }^{4}$, Valérie Gélin ${ }^{1,2}$, Julien Cohen ${ }^{5}$, Arnaud Fauconnier ${ }^{3,6}$, François Vialard ${ }^{1,2,3}$, Cyrille Huchon ${ }^{3,7,8}$ and Pascale Chavatte-Palmer ${ }^{1,2}$

\begin{abstract}
Background: Pressurized Intra-Peritoneal Aerosol Chemotherapy (PIPAC) is an innovative treatment against peritoneal carcinomatosis. Doxorubicin is a common intra-venous chemotherapy used for peritoneal carcinomatosis and for PIPAC. This study evaluated the impact of increased PIPAC intraperitoneal pressure on the distribution and cell penetration of doxorubicin in a sheep model.
\end{abstract}

Methods: Doxorubicin was aerosolized using PIPAC into the peritoneal cavity of 6 ewes (pre-alpes breed): $N=3$ with $12 \mathrm{mmHg}$ intraperitoneal pressure ("group 12") and $\mathrm{N}=3$ with $20 \mathrm{mmHg}$ ("group 20"). Samples from peritoneum $(N=6)$, ovarian $(N=1)$, omentum $(N=1)$ and caecum $(N=1)$ were collected for each ewe. The number of doxorubicin positive cells was determined using the ratio between doxorubicine fluorescence-positive cell nuclei $(\mathrm{DOXO}+)$ over total number of DAPI positive cell nuclei (DAPI+). Penetration depth $(\mu \mathrm{m})$ was defined as the distance between the luminal surface and the location of the deepest DOXO+ nuclei over the total number of cell nuclei that were stained with DAPI. Penetration depth $(\mu \mathrm{m})$ was defined as the distance between the luminal surface and the location of the deepest DOXO+ nuclei.

Results: $\mathrm{DOXO}+$ nuclei were identified in $87 \%$ of samples. All omental samples, directly localized in front of the nebulizer head, had 100\% DOXO+ nuclei whereas very few nuclei were DOXO+ for caecum. Distribution patterns were not different between the two groups but penetration depth in ovary and caecum samples was significantly deeper in group 20.

(Continued on next page)

\footnotetext{
* Correspondence: myriam.mimouni@ght-yvelinesnord.fr

${ }^{1}$ Université Paris-Saclay, UVSQ, INRAE, BREED, 78350 Jouy-en-Josas, France

2Ecole Nationale Vétérinaire d'Alfort, BREED, 94700 Maisons-Alfort, France

Full list of author information is available at the end of the article
}

C C The Author(s). 2021 Open Access This article is licensed under a Creative Commons Attribution 4.0 International License, which permits use, sharing, adaptation, distribution and reproduction in any medium or format, as long as you give appropriate credit to the original author(s) and the source, provide a link to the Creative Commons licence, and indicate if changes were made. The images or other third party material in this article are included in the article's Creative Commons licence, unless indicated otherwise in a credit line to the material. If material is not included in the article's Creative Commons licence and your intended use is not permitted by statutory regulation or exceeds the permitted use, you will need to obtain permission directly from the copyright holder. To view a copy of this licence, visit http://creativecommons.org/licenses/by/4.0/ The Creative Commons Public Domain Dedication waiver (http://creativecommons.org/publicdomain/zero/1.0/) applies to the data made available in this article, unless otherwise stated in a credit line to the data. 
(Continued from previous page)

Conclusions: This study showed that applying a higher intra-peritoneal pressure during PIPAC treatment leads to a deeper penetration of doxorubicin in ovarian and caecum but does not affect distribution patterns.

Keywords: Sheep, Doxorubicin, PIPAC, Intraperitoneum pressure, Peritoneal carcinomatosis

\section{Background}

Peritoneal carcinomatosis (PC) is a peritoneal metastasis of many cancers, especially ovarian cancer. In France, ovarian cancer affects 4600 women and induces 3200 deaths annually (Institut National du Cancer 2015). The first intention treatment is the association of complete surgery in addition to platinum based-chemotherapy [1]. PC often extends to the whole abdomen, from the diaphragm peritoneum down to the pelvis. The extensive size of the affected zone is the main difficulty for the surgical treatment of ovarian cancer as completeness of the initial surgery is one of the two main prognostic factors. Resistance to chemotherapy is the second most important reason for relapse [2]. Despite optimal treatment, $70 \%$ of patients with ovarian cancer relapse within 5 years [3] and 1 in 4 will become platinumresistant (relapse within 6 months after platinumcontaining therapy) [4]. For these patients, therapeutic possibilities become rare and prognosis is poor [5]. Although the recent availability of bevacizumab treatment improved the survival rate of these patients, surgery is rarely feasible and the effects of chemotherapy remain limited. Thus, finding new therapies for these patients remains urgent [6].

In most cases, ovarian cancer is restricted to the peritoneal cavity without distant organic metastasis (stade IIIC in FIGO classification) [7]. This is the ideal target for intra-peritoneal treatment. In 2012, a new method for intra-peritoneal administration of chemotherapy, Pressurized Intra-Peritoneal Aerosol Chemotherapy (PIPAC), was developed, where the chemotherapy is nebulized at body temperature in the intra-peritoneal cavity during laparoscopy [8]. The conversion of liquid chemotherapy into droplets is thought to enable homogeneous peritoneal distribution. Moreover, compared to a simple lavage, drug administration under the pressure used for the laparoscopy was shown to induce a better penetration of drugs in an in vitro model [9]. Finally, the plasmatic uptake of chemotherapeutic drugs is negligible, thus limiting side effects of chemotherapy [10, 11]. The standard intra-abdominal pressure used in the initial published protocol was $12 \mathrm{mmHg}$ [12], which has been applied for clinical use.

So far, clinically, doxorubicin, which is commonly used for the chemotherapy of ovarian cancers, is also used with the PIPAC procedure. It acts through the inhibition of DNA transcription. Three interventions at 4-6 weeks interval each were shown to largely reduce peritoneal carcinomatosis $[13,14]$. Furthermore, the patients' quality of life of being seems to be maintained when treated with PIPAC chemotherapy $[15,16]$. These encouraging pioneer data prompt the needs for further evaluation and improvement $[17,18]$.

In this context, the objective of our study was to compare the penetration and the distribution of doxorubicin administered with PIPAC using two distinct intraperitoneal pressures (12 and $20 \mathrm{mmHg}$ ).

Experiments were carried out in sheep, of similar size and weight to humans, so that the same equipment could be used. None of the large domestic animals spontaneously nor experimentally develop ovarian cancer similar to humans, so a healthy model was used.

\section{Methods \\ Ethical statement}

The project was approved by the local ethics committee $\left(\mathrm{N}^{\circ} 16\right.$ in the French registry of ethical committees) of animal experimentation of the National Veterinary School of Alfort and validated by the French Ministry of Research under registration "APAFIS" number 2016113016134972. Sheep were euthanized under general anaesthesia after PIPAC procedure and before sampling (Directive 2010/63/UE of European Parliament and Council dated September 22nd, 2010). This was performed by a trained team. All precautions were taken to limit anxiety and pain of the animals.

\section{Experimental plan}

Altogether, 10 non-pregnant multiparous ewes were used. The first three animals were used for preliminary tests and development of the model. Thereafter, PIPAC was carried out as follows: (i) one control female with physiological serum, (ii) three females with a capnoperitoneum at $12 \mathrm{mmHg}$ (group 12), and (iii) 3 females with a capnoperitoneum at $20 \mathrm{mmHg}$ (group 20). To avoid a potential "day" effect, procedures for group 12 and 20 were performed alternatively (2-3 procedures/day). Animal characteristics are described in Table 1.

\section{Surgical procedure}

All PIPAC procedures were performed in the surgery theatre of the Biomedical research center (CRBM) of the National Veterinary School of Alfort. 
Table 1 Characteristics of ewes used for PIPAC experiments

\begin{tabular}{llll}
\hline $\begin{array}{l}\text { Sheep } \\
\text { (procedural order) }\end{array}$ & $\begin{array}{l}\text { Weight } \\
(\mathbf{K g})\end{array}$ & Capnoperitoneum $(\mathbf{m m H g})$ & Group \\
\hline control & 52 & 12 & control \\
1 & 51 & 12 & 1 \\
2 & 46 & 20 & 2 \\
3 & 54 & 12 & 1 \\
4 & 47 & 20 & 2 \\
5 & 45 & 12 & 1 \\
6 & 51 & 20 & 2 \\
\hline
\end{tabular}

\section{General anaesthesia}

The anaesthesia was carried out by a trained team. Animals were fasted for $12-16 \mathrm{~h}$ before surgery. After a premedication with ketamine (Imalgen $1000^{\circ}$, Merial, $4 \mathrm{mg} /$ $\mathrm{kg} \mathrm{IV)} \mathrm{and} \mathrm{diazepam} \mathrm{(Diazepam,} \mathrm{TVM,} 0.5 \mathrm{mg} / \mathrm{kg}$ IV), anaesthesia was maintained with an automated ventilator, using isofluorane (2-2.5\%) diluted in a mixture of air and oxygen (50/50). Analgesia was ensured by IV injection of fentanyl (Fentadon ${ }^{\oplus}$, Eurovet Animal Health, $2 \mu \mathrm{g} / \mathrm{kg}$ IV) per hour. Per-operating supervision focused on respiratory rate, cardiac frequency, oxygen saturation and arterial pressure.

\section{PIPAC: surgical procedure}

The PIPAC was performed according to the safety rules described by Solaß (2013). All precautions were taken to ensure staff safety: every operator wore a surgical blouse, gloves, protection glasses and a high protection breathing mask.

After clipping the anterior abdominal wall, points were drawn on the skin for trocar localization, $6 \mathrm{~cm}$ (laparoscopic camera) and $18 \mathrm{~cm}$ (nebulizer) below the umbilicus. Two $12 \mathrm{~mm}$-incisions were made at these localizations (open-laparoscopy) and two $12 \mathrm{~mm}$-balloon trocars (Medtronic ${ }^{\circledR}$, Autosuture $12 \mathrm{~mm}, \mathrm{BTT}$, Covidien) were inserted, ensuring tightness of the abdomen and steadiness of the pressure (Fig. 1). A capnoperitoneum was established and a camera was introduced in the abdomen for a short exploration phase. The nebuliser (MIP ${ }^{\star}$, Reger Medizintechnik, Tottweil, Germany) was connected to the high-pressure injector using a highpressure injection line (Medrad, Mark 7, Arterion ${ }^{\circledR}$, Bayer). The distal part of the nebulizer was positioned at a $1 \mathrm{~cm}$ depth, as measured from the trocar end. The sheep was placed in Trendelenbourg position to raise the rumen and provide a better exposition of the pelvis. Three milligrams of doxorubicin (Mylan ${ }^{\circ}, 2 \mathrm{mg} / \mathrm{mL}$ ) diluted in $50 \mathrm{~mL}$ saline were nebulized at a flowrate of 30 $\mathrm{mL} /$ minute with a maximum pressure of $200 \mathrm{psi}$, as usually recommended in human patients [19]. After nebulization, the capnoperitoneum was maintained during 30 min. The abdomen was subsequently deflated using an

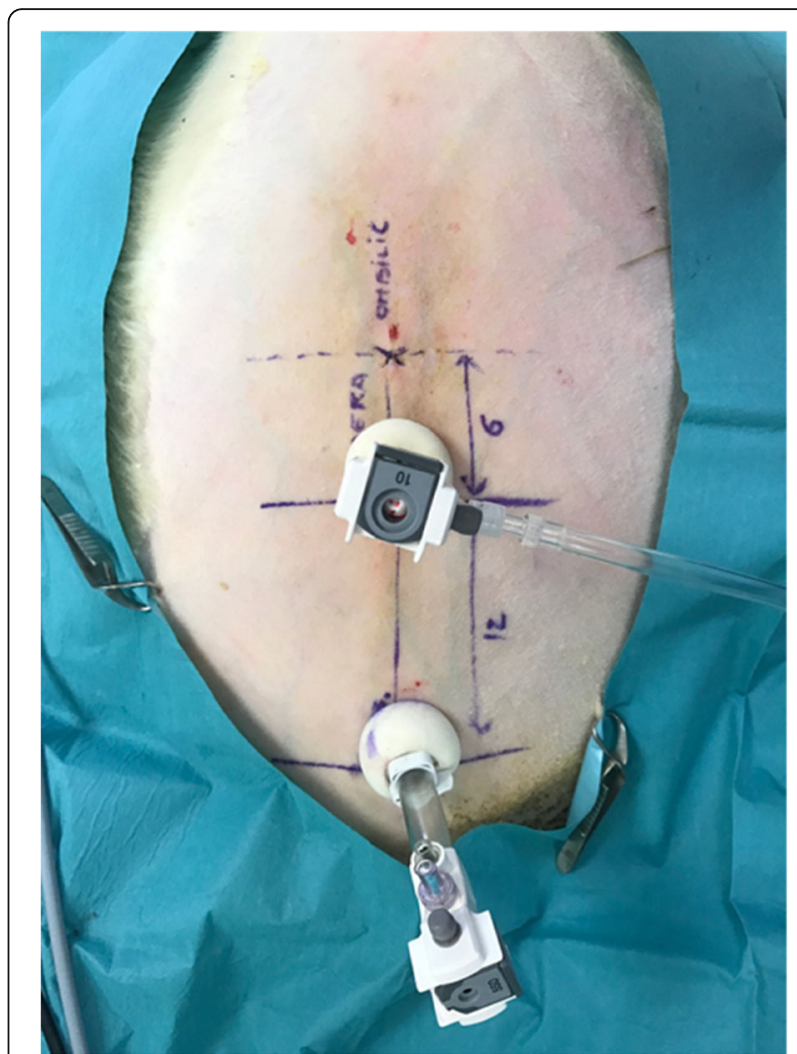

Fig. 1 Localization of trocars on sheep's abdominal wall

airtight device equipped with a smoke filter and connected to the waste air system in order to avoid contamination of the surgical room with doxorubicin. Thirty additional minutes were allowed for optimum drug penetration in tissues before the animal was euthanized with pentobarbital (Dolethal ${ }^{\circ}$, Vetoquinol, 3.6 g, i.e., 20 $\mathrm{ml}, \mathrm{IV})$. A median laparotomy was performed and 9 samples (6 peritoneal, 1 ovarian, 1 omental and 1 ceacal) were collected (Fig. 1). One more sample (omentum) was collected just facing the nebulizer. In order to ensure the reproducibility of the sampling for each animal, positions of the peritoneal samples were annotated relatively to their distance to the nebulizer (Fig. 2). Samples were immediately frozen in isopentane at $-40{ }^{\circ} \mathrm{C}$ after horizontal inclusion in Optimum Cutting Temperature (Tissue-Tek ${ }^{\diamond}$ O.C.T. Compound, Sakura ${ }^{\circledR}$ Finetek). Blocks were kept frozen at $-80^{\circ} \mathrm{C}$.

\section{Microscopic analyses}

All analyses were performed blindly. The natural fluorescent properties of doxorubicin was used for its localization in the tissues [20]. Samples were handled in a dark room to avoid light exposure that may decrease fluorescence.

Sections $(7 \mu \mathrm{m})$ were cut using a cryostat (Leica ${ }^{\circledR}$ CM1950), then mounted with $25 \mu \mathrm{L}$ anti-fade mounting 


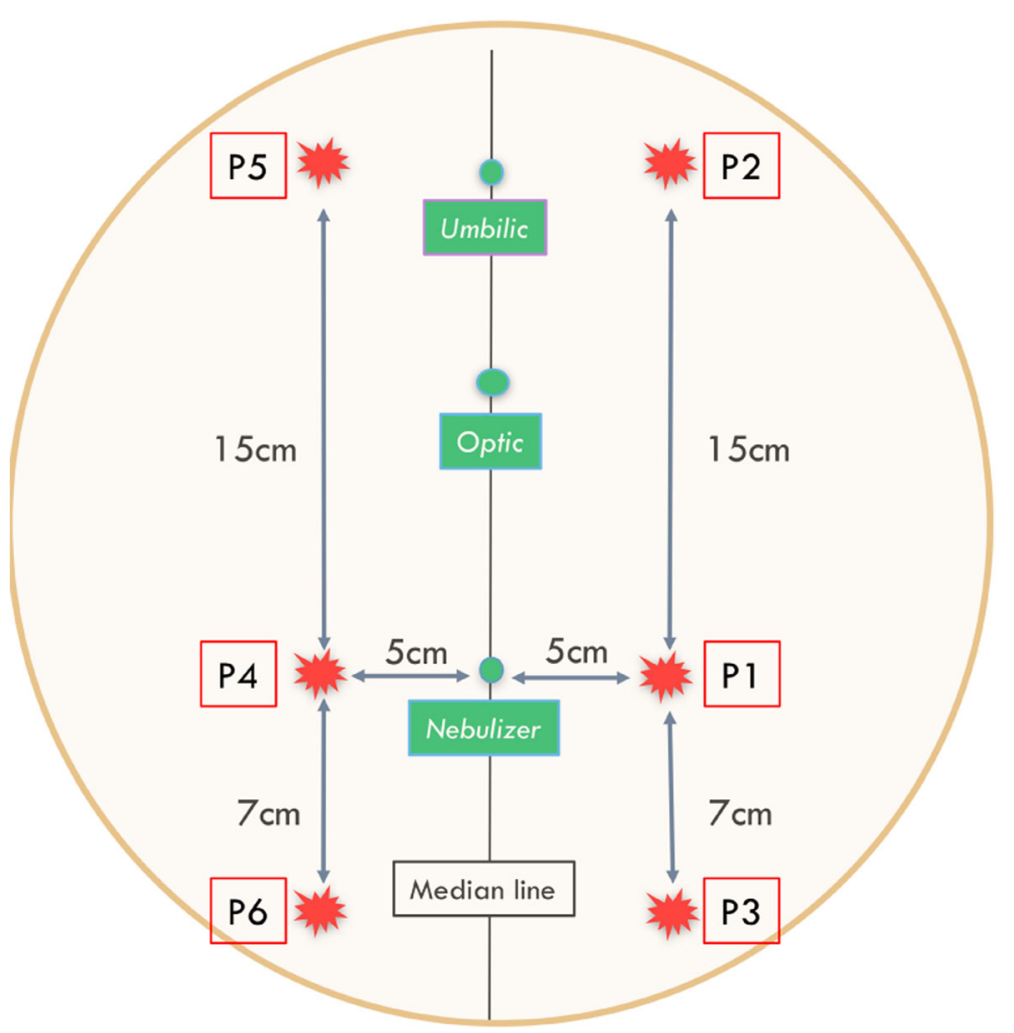

Fig. 2 Standardized location of peritoneal samples (P1 to P6) according to distance to nebulizer. Figure 2 Identification of doxorubicin in nuclei. * Nuclei DAPI+: nuclei stained by DAPI. Nuclei DOXO+: nuclei stained by Doxorubicin and DAPI

medium (Vectashield ${ }^{\oplus}$, Vector laboratories) that contained with 4,6-diamidino-2phenylindole (DAPI) at $1 /$ 1000. They were kept at $4^{\circ} \mathrm{C}$ until observation.

Analyses were performed with a Carl Zeiss (Germany) AxioObserver $\mathrm{Z} 1$ fluorescence microscope equipped with an ApoTome slider and coupled to AxioVision 4.8 software (Zeiss). A complete brightfield view of the section was imaged using a 10x Plan-Neofluar (NA 0.3) objective and 10 square areas of about $200 \mu \mathrm{m}$ side length were randomly selected. Then fluorescence analysis of each area was performed using a Plan Neofluar X40 oil immersion (NA 1.3) objective and an Axiocam MRm camera (Zeiss). Nuclei were identified using DAPI (blue). Doxorubicin positive nuclei (DOXO+) were stained both in orange and blue. Cytoplasm and extracellular stroma fluoresced in orange together with green auto-fluorescence (Figs. 3 and 4). The time for image acquisition was similar for each fluorochrome throughout the experiments. Fluorescence setup and image acquisition times are detailed in Table 2. Since all images were in the same horizontal plane, fluorescence was not decreased depending on tissue depth.

\section{Statistical analyses}

Statistical analyses were performed with data collected from the 6 doxorubicin PIPAC-treated sheep. All analyses were performed with SPSS v15.0 and Stata v12.0 software (Stata Corp., College Station, TX, USA). Effect of treatment was analyzed using individual sample location, distance to nebulizer (for peritoneum, distinguishing frontal, proximal and distal samples) and histological type as variables.

Tissue distribution patterns of doxorubicin positive cells were assessed by measuring the ratio of $\mathrm{DOXO}+1$ DAPI+ nuclei. For each tissue sample, DAPI + and

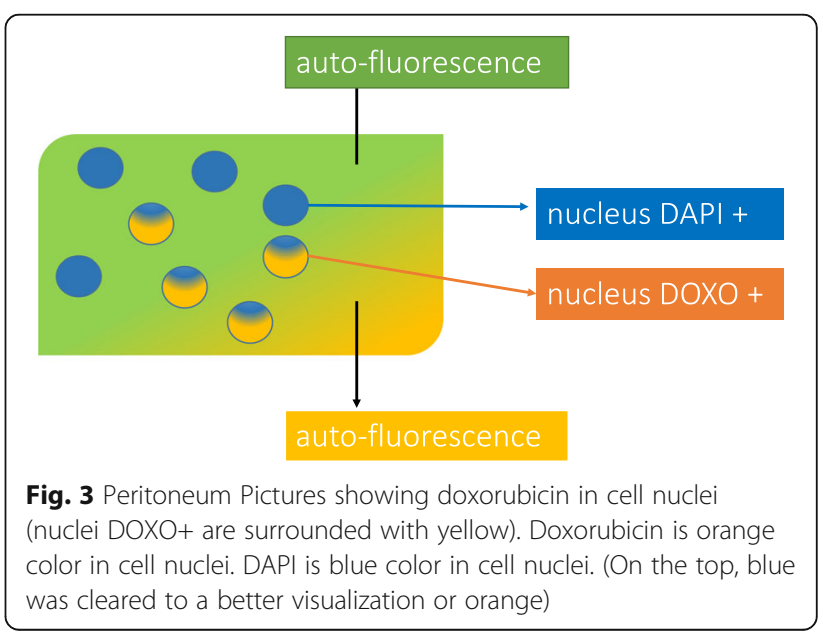




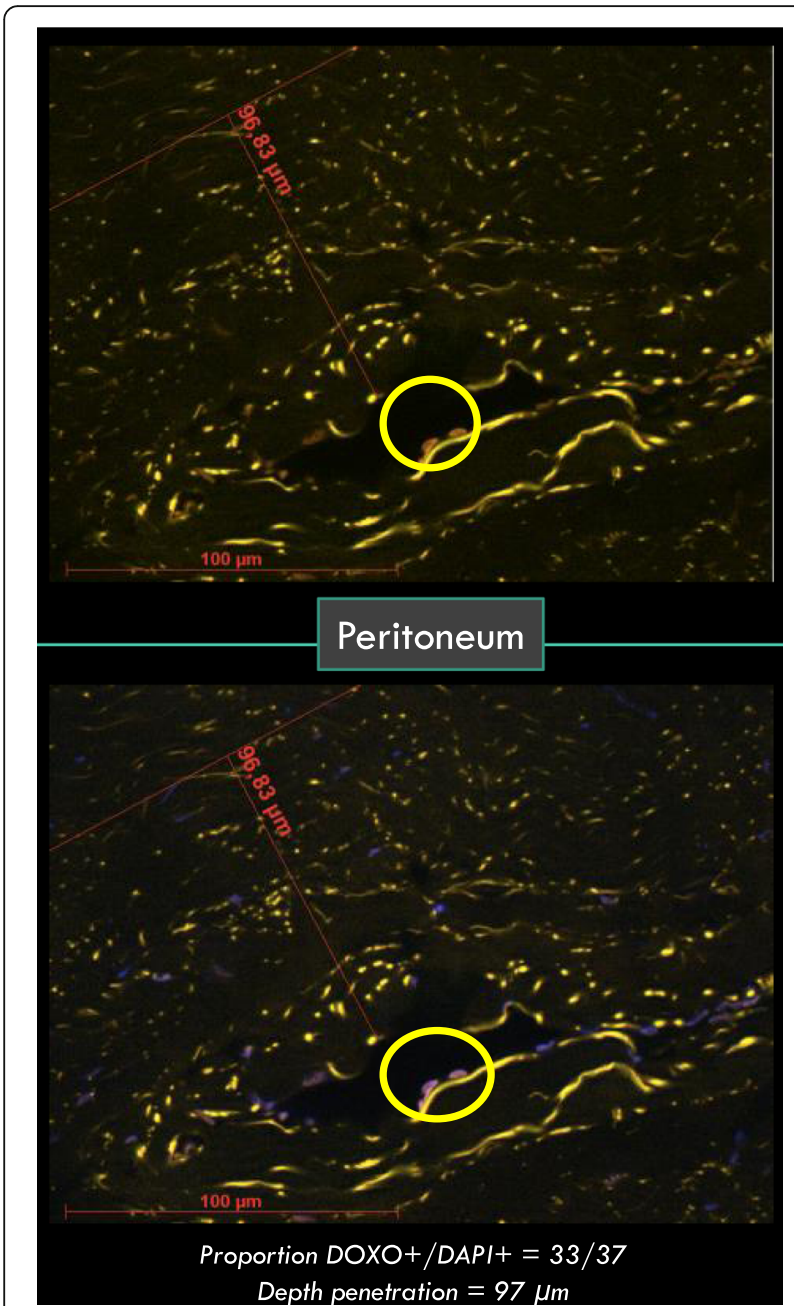

Fig. 4 Description and comparison of intra-peritoneal distribution pattern of doxorubicin for each histological type

DOXO + positive cells were counted for each of the 10 square areas and summed up. A Mann-Whitney test was used to analyze the effect of increased intra-peritoneal pressure on the distribution pattern of doxorubicin according to the histological type and location of the sample related to the nebulizer.

Penetration depth of doxorubicin was estimated by measuring the distance between the luminal surface of the tissue and the deepest $\mathrm{DOXO}+$ nuclei that were identified. Samples showing no doxorubicin were removed from analysis. The drug penetration depth was analyzed for each histological type and sample location. Tissue drug penetration was classified in 2 categories: < $100 \mu \mathrm{m}$ and $\geq 100 \mu \mathrm{m}$ for group comparison. In order to take into account the correlation between samples from the same ewe, a GEE model (Generalized Estimating Equation) was used [21] to compare penetration depth between the two groups. When one single sample was collected from each animal (ovary, caecum and omentum), drug penetration was compared using a one tailed Chi2 test.

\section{Results}

\section{Distribution patterns of doxorubicin}

No nuclear fluorescence in the $>520 \mathrm{~nm}$ wavelength (corresponding to the fluorescence signal emitted by doxorubicin) was observed in any tissue collected in the control ewe.

Doxorubicin was observed in 47 samples of the 54 collected (87\%). Pressure increase had no effect on the distribution patterns of doxorubicin regardless of the tissue or peritoneal localization (Figs. 5 and 6). Cell nuclei distribution patterns of doxorubicin were heterogeneous in the peritoneal tissue. Almost all omental nuclei were $\mathrm{DOXO}+(99 \%)$ whereas the caecum rarely stained positive (17\%). Interestingly, in 4 of the 6 ovaries, DOXO+ cells were only found on one side of the ovary and not on the other (Fig. 7).

\section{Penetration depth of doxorubicin}

Similar to cell distribution, penetration depth of doxorubicin was heterogeneous in the peritoneum with no significant difference between groups $(p=0,69)$ when analysed altogether.

Penetration depth was $>100 \mu \mathrm{m}$ in all group 20 ovarian samples versus only 55\% in group 12 . There was a significant difference in penetration depth in the caecum between the 2 groups (100\% for group 20 versus $22 \%$ for group 12). Regarding the omentum, $100 \%$ of sampled tissues showed a penetration depth $>100 \mu \mathrm{m}$, regardless of the intraabdominal pressure. These results are summarized in Table 3.

Table 2 Characteristics and signification of fluorescence for orange, blue and green

\begin{tabular}{llllll}
\hline & Excitation & Emission & Time of acquisition & Origin of fluorescence & Localisation of fluorescence \\
\hline Vert & $470 \mathrm{~nm}$ & {$[500-550]$} & $900 \mathrm{~ms}$ & autofluorescence & Extra-nuclear \\
Bleu & $365 \mathrm{~nm}$ & $>400$ & $10 \mathrm{~ms}$ & DAPI & Cell nuclei \\
Orange & $470 \mathrm{~nm}$ & $>520$ & $900 \mathrm{~ms}$ & Auto-fluorescence & Extra-nuclear \\
& & & & DOXORUBICIN & Cell-nuclei \\
\hline
\end{tabular}




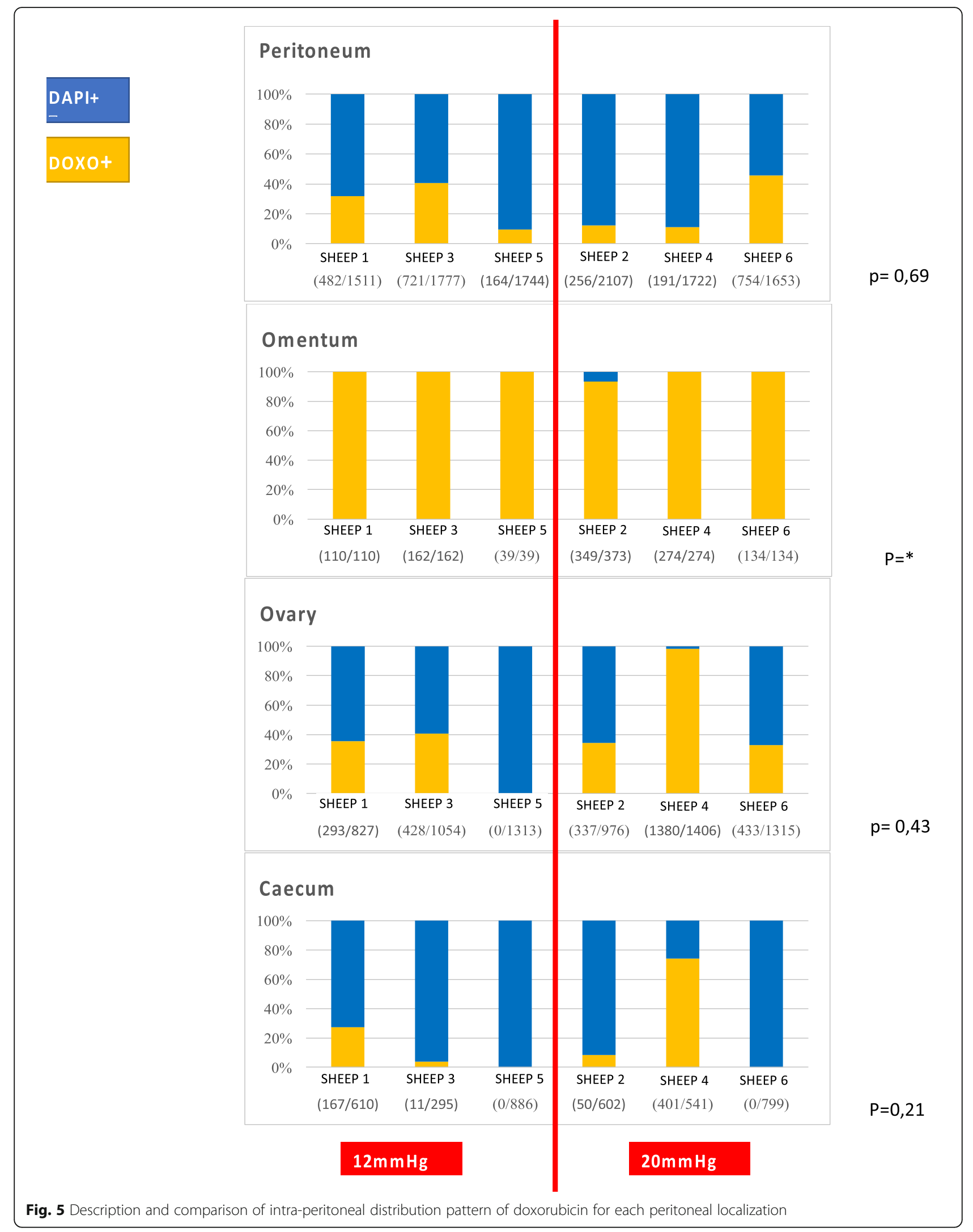




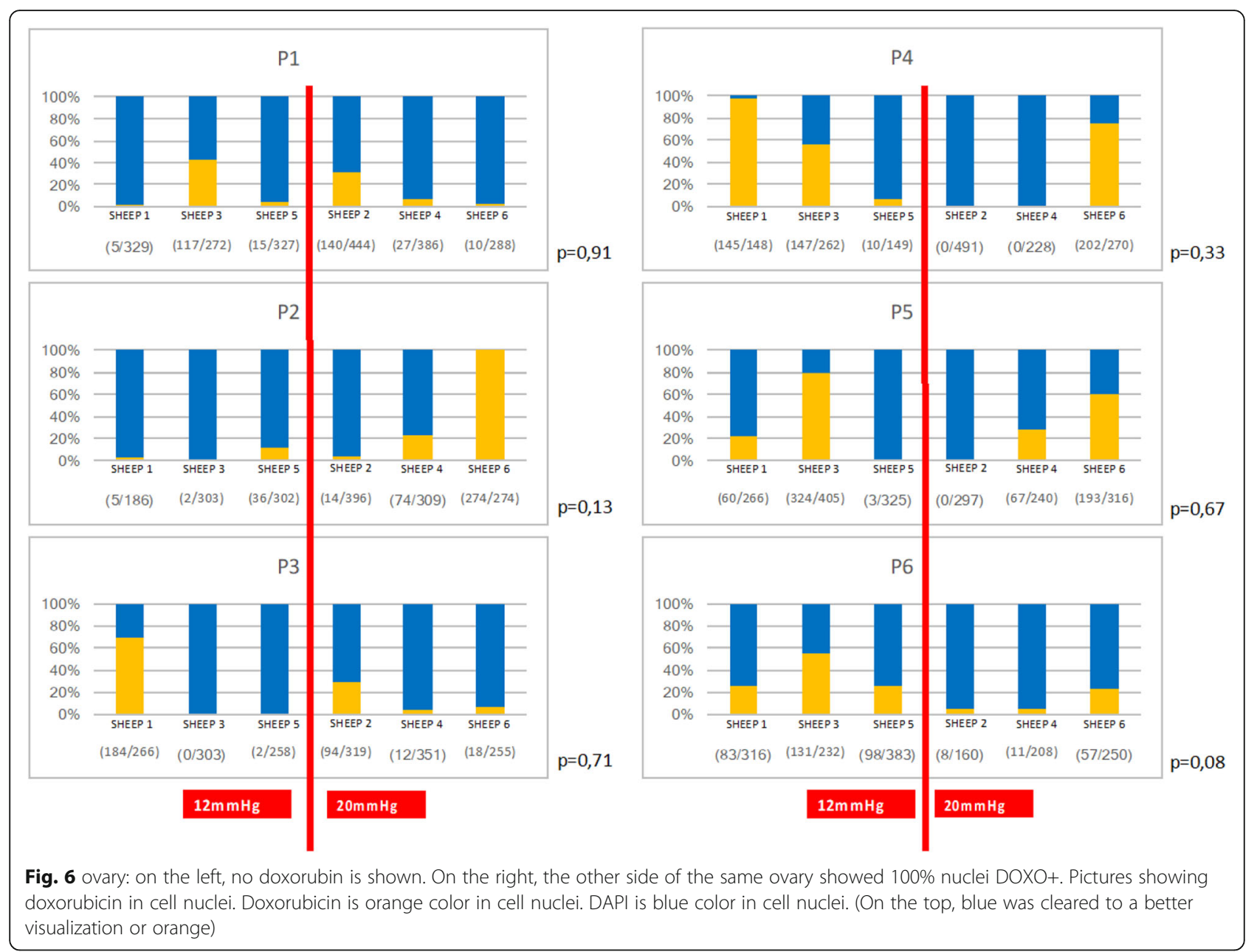

\section{Discussion}

In this study, a sheep model of PIPAC-doxorubicin was developed to evaluate the impact of intra-peritoneal pressure on two parameters, namely the number of doxorubicin-positive cells and their localization relatively to the surface of the tissue (penetration depth). The sheep is human-sized model, and the same parameters and surgical conditions are used as in human patients, making it very relevant for clinical practice.

This is the first report assessing the impact of increased intra-abdominal pressure on penetration depth of chemotherapy. Penetration depth in the ovaries and caecum was significantly increased with a pressure at 20 $\mathrm{mmHg}$ compared to $12 \mathrm{mmHg}$ but this increase was not consistent over all peritoneal samples. In the mouse model, Jacquet and Sugarbaker evaluated the effect of intra-abdominal pressure $(12,20$ and $30 \mathrm{mmHg}$ ) on doxorubicin concentration in peritoneal tissues after the abdominal cavity was treated with doxorubicin as a simple lavage [22]. They showed that a higher pressure significantly increased doxorubicin penetration into the tissue. Nevertheless, a $30 \mathrm{mmHg}$ intra-abdominal pressure induced toxic effects, especially on digestive organs (necrosis). The impact of increased pressure $(5,10$, 15 and $20 \mathrm{mmHg}$ ) was also studied in vitro using colon adenocarcinoma cells [23], with cytotoxic effects being significantly increased and proportional to pressure. The same team evaluated the effect of increased pressure on penetration depth of doxorubin in an ex vivo study (fresh porcine peritoneal tissue in a hermetically closed chamber) and did not demonstrate any significant effect [24]. These experiments suggest that peritoneal cells may be less permeable to doxorubicin that other cell types, as also observed in the present study. The formation of a liquid film on the peritoneum after PIPAC may also contribute to the poorer effects of increased intraabdominal pressure on the peritoneum [25].

Compared to $12 \mathrm{~mm}$ HG pressure, intra-abdominal pressure at $20 \mathrm{mmHg}$ did not significantly affect the number of $[\mathrm{DOXO}+]$ cells in peritoneal cavity, nor in omemtum, ovary and caecum. Regardless of the pressure, distribution of [DOXO+] cells was heterogeneous and did not reach all areas. These results are consistent with the results of experiments performed in vivo and 


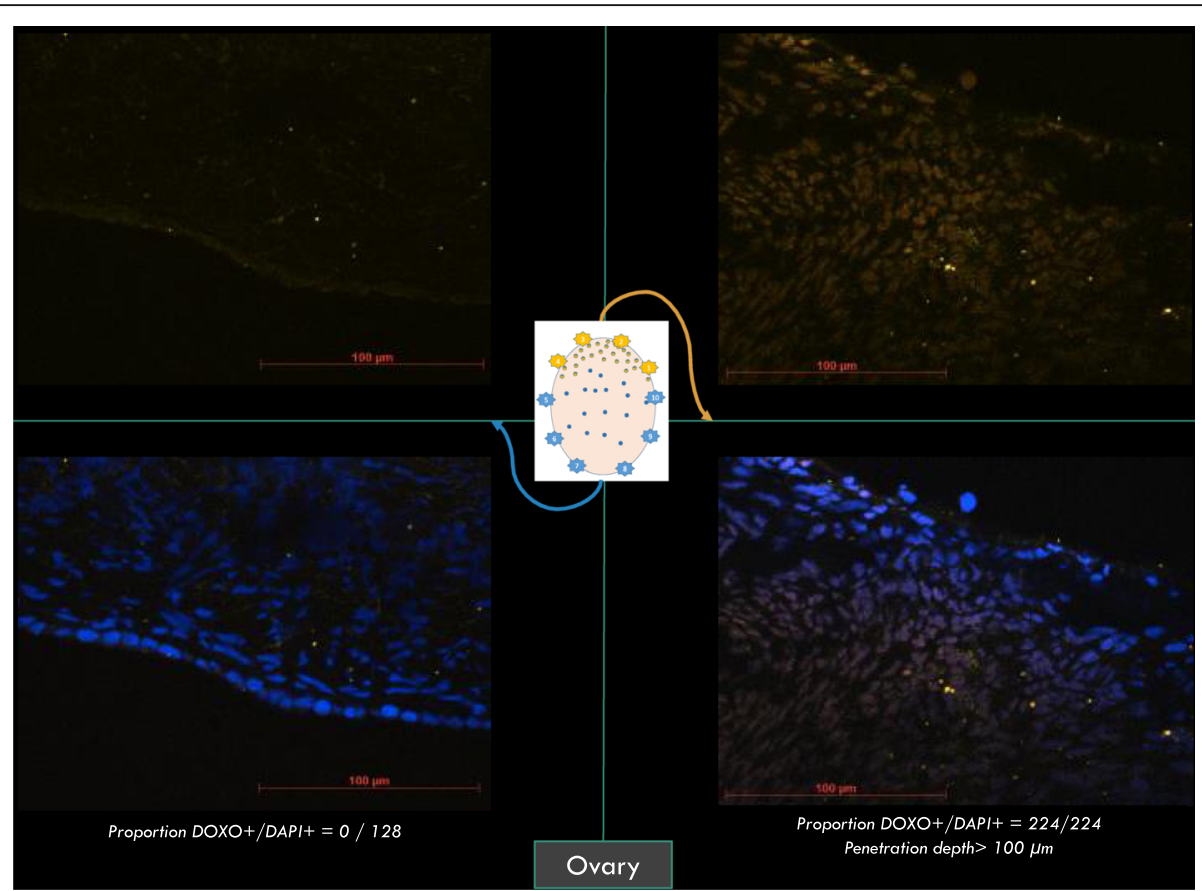

Fig. 7 Ovary: on the left, no doxorubin is shown. On the right, the other side of the same ovary showed 100\% nuclei DOXO+ Pictures showing doxorubicin in cell nuclei. Doxorubicin is orange color in cell nuclei. DAPI is blue color in cell nuclei. (On the top, blue was cleared to a better visualization or orange)

post mortem on swine [22, 26]. In an attempt to improve these results, electrostatic precipitation of the aerosol (ePIPAC) could help homogenizing the distribution pattern of doxorubicin [27, 28]. Moreover, the omentum, facing the nebulizer, always had the highest number of $[\mathrm{DOXO}+]$ cells together with the deepest penetration. In contrast to the omentum, the lowest number of $[\mathrm{DOXO}+]$ cells was found in the caecum,

Table 3 Comparison of penetration depth of doxorubicin after PIPAC with a pressure at $12 \mathrm{mmHg}$ (group12) and PIPAC with a pressure at $20 \mathrm{mmHg}$ (group20)

\begin{tabular}{|c|c|c|c|c|c|}
\hline \multirow[t]{2}{*}{ Peritoneum } & \multicolumn{2}{|c|}{$\begin{array}{l}\text { Group } 12 \\
(12 \mathrm{mmHg}) \\
\mathrm{n} / \mathrm{N}(\%)\end{array}$} & \multicolumn{2}{|c|}{$\begin{array}{l}\text { Group } 20 \\
(20 \mathrm{mmHg}) \\
\mathrm{n} / \mathrm{N}(\%)\end{array}$} & \multirow{2}{*}{$\begin{array}{l}p \text {-value } \\
0.69\end{array}$} \\
\hline & $34 / 95$ & $(36)$ & $23 / 82$ & $(28)$ & \\
\hline P1 & $4 / 9$ & $(44)$ & $1 / 16$ & (6) & 0.08 \\
\hline P2 & $0 / 11$ & (0) & $10 / 20$ & (50) & * \\
\hline P3 & $9 / 10$ & $(90)$ & $3 / 11$ & (27) & 0.11 \\
\hline P4 & $16 / 24$ & $(67)$ & $3 / 10$ & (30) & 0.38 \\
\hline P5 & $5 / 19$ & $(26)$ & $5 / 17$ & (29) & 0.79 \\
\hline P6 & $0 / 22$ & (0) & $1 / 8$ & (13) & $*$ \\
\hline Ovary & $6 / 11$ & $(55)$ & $15 / 15$ & $(100)$ & * \\
\hline Omentum & $20 / 20$ & $(100)$ & $26 / 26$ & $(100)$ & $*$ \\
\hline Caecum & $2 / 9$ & $(22)$ & $8 / 8$ & $(100)$ & * \\
\hline
\end{tabular}

$\mathrm{n}=$ number of samples showing a penetration depth $>100 \mu \mathrm{m}$ $\mathrm{N}=$ number of samples showing presence of doxorubicin which could be explained by anatomical localisation. Apart from the presence of 4 stomachs, the abdominal anatomy of human and sheep is very similar for almost all abdominal organs, but for the bicornuate uterus in sheep instead of uterus simplex in humans. The most voluminous stomach in ruminants is the rumen (anatomically first and largest of the 4 stomachs of ruminants), that occupies the major part of the peritoneal cavity. The caecum was mostly hidden by the rumen during the nebulization process, despite the use of the Trendelenbourg position. This suggests that PIPAC administered chemotherapy does not reach tissues that are positioned beneath other organs, as exemplified with our observations for ovaries where doxorubicin only reached the ovarian side exposed to the nebulization. This observation could have important consequences in clinical practice. Nowadays, patients with recurrent peritoneal carcinomatosis from ovarian cancer often undergo an initial treatment with large abdominal surgery. These surgeries currently induce adherences between organs, thus potentially reducing access to many surfaces at the time when PIPAC is used. In any case, in practice, changing the direction of the trocar during the nebulization may help reach more peritoneal surface.

The data and conclusions drawn from this study deserve to be confirmed with a larger number of animals. Nevertheless, a significant effect of increased intraabdominal pressure on penetration depth of doxorubicin 
was observed, suggesting that this should be further explored in clinical conditions. Furthermore, the experiments were performed on healthy tissues and the effect of pressure on doxorubicin penetration could be different on cancerous cells. Peritoneal carcinomatosis is not currently observed in domestic animals and large animal models of peritoneal carcinomatosis are required because laparoscopy and PIPAC could not be performed on rodent nor rabbit models. Finally, it could have been interesting to measure plasma concentration of doxorubicin in the 2 groups in post-operative period to evaluate systemic uptake of doxorubicin. However, sheep were euthanized at the end of procedure as designed in the experimental protocol and this was not performed in the present study.

\section{Conclusion}

Increased pressure was shown to increase penetration depth of doxorubicin in healthy abdominal tissues, suggesting that increased pressure may improve the efficiency of PIPAC on tumoral tissues in clinical practice. In order to confirm these encouraging results, large animal models such as sheep or pigs with peritoneal carcinomatosis should be developed for the benefit of oncologic research and especially PIPAC. Many studies could be performed to evaluate PIPAC efficiency on human patients suffering from carcinomatosis disease. Based on the present data, studies focusing on penetration depth on peritoneal carcinomatosis would be very informative, as these are much more cellular than healthy tissues. It could also be worth comparing the plasma concentrations of chemotherapeutic drugs in relation to variations of the capnoperitoneum.

Moreover, it would be interesting to study whether the efficiency of PIPAC in human patients could be improved from using both ePIPAC and high capnoperitoneum. Finally, the present study could suggest that directing the nebulizer towards the most affected carcinomatosis areas could improve the efficiency of the procedure, which needs to be evaluated.

\footnotetext{
Abbreviations

PIPAC: Pressurized Intra-Peritoneal Aerosol Chemotherapy; DOXO +: Doxorubicine fluorescence-positive cell nuclei; DAPI : 4,6-diamidino-2phenylindole; DAPI+ : DAPI positive cell nuclei; ENVA : Ecole Nationale Vétérinaire d'Alfort; PC: Peritoneal carcinomatosis; CRBM: Biomedical Research Center; GEE: Generalized Estimating Equation
}

\section{Acknowledgements}

The authors wish to acknowledge the support of CIMA and MIMA2 imaging platforms at INRA Jouy-en-Josas and the CRBM at ENVA (Ecole Nationale Vétérinaire d'Alfort).

Availability of data and materials' section

All data generated or analysed during this study are included in this published article.

\section{Authors' contributions}

MM, FV, CH, AT, OS and PCP designed in vivo experiments. MM drafted ethic protocol and PCP and TL revised it. MM, TL and PCP MM, PA and ML designed the microscopic fluorescent analyses. MM and CR performed the in vivo procedures of PIPAC. BL and VG participated and helped for every PIPAC procedures. AF and JC performed data analysis. MM, PCP, PA, OS, FV and CH discussed the results. MM has drafted the manuscript and PCP and $\mathrm{CH}$ substantively revised it. All authors read and approved the final manuscript.

\section{Funding}

This study was funded by the Cancer network of North Yvelines chaired by Yvan Coscas (sheep, nebulizers and experiments equipment) and the Research Institute on Women's Health (IRSF) chaired by Arnaud Fauconnier (High Pressure injector)

\section{Declarations}

\section{Ethics approval and consent to participate}

The project was approved by the local ethics committee of animal experimentation of the National Veterinary School of Alfort and was registered under "APAFIS 2016113016134972" number by the relevant national authorities. All anaesthesia, analgesia and surgical procedures were carried out by an habilitated and expert team.

\section{Consent for publication}

No applicable.

\section{Competing interests}

The authors declare that they have no competing interests.

\section{Author details}

${ }^{1}$ Université Paris-Saclay, UVSQ, INRAE, BREED, 78350 Jouy-en-Josas, France. ${ }^{2}$ Ecole Nationale Vétérinaire d'Alfort, BREED, 94700 Maisons-Alfort, France.

${ }^{3}$ Department of Gynecology and Obstetrics, 10 rue du Champ Gaillard, CHI Poissy-Saint-Germain, 78300 Poissy, France. ${ }^{4}$ Centre de Recherche BioMédicale (CRBM), ENVA, UPE, Maisons-Alfort, France. ${ }^{5}$ Medistat, Biostatistics, 10-12 rue de la Conception, 13004 Marseille, France. ${ }^{6}$ Department of Pharmacy, 10 rue du Champ Gaillard, CHI Poissy-Saint-Germain, Poissy, France. ${ }^{7}$ EA 7285 Clinical Risks and Safety on Women's Health, University Versailles-Saint-Quentin en Yvelines, 2 avenue de la Bièvre, 78180 Montigny le Bretonneux, France. ${ }^{8}$ APHP. Department of Gynecology and Obstetrics, Hôpital Lariboisière, University of Paris, 2, rue Ambroise Paré, 75010 Paris, France.

Received: 22 May 2020 Accepted: 23 February 2021

Published online: 26 April 2021

\section{References}

1. European Society of Gynaecological Oncology ESGO Ovarian Cancer Surgery Guidelines_v2, http://Guidelines.Esgo.Org/Media/2017/03/ESGO_ova rian_cancer_surgery_brA5_V01-Website.Pdf.

2. Bristow RE, Thomacruz R, Armstrong D, et al. Recurrent Micropapillary Serous Ovarian Carcinoma. Cancer. 2002;95:791-800. https://doi.org/10.1200/ JCO.2002.20.5.1248.

3. Cannistra SA. Cancer of the Ovary. New England J Med. 2004;351:2519-29. https://doi.org/10.1056/NEJMra041842.

4. Al Rawahi T, Lopes A, Bristow E, et al. 'Surgical Cytoreduction for Recurrent Epithelial Ovarian Cancer. Cochrane Database Systematic Rev. 2013;2. https://doi.org/10.1002/14651858.CD008765.pub3.

5. Hanker LC, Loibl S, Burchati N, et al. The Impact of Second to Sixth Line Therapy on Survival of Relapsed Ovarian Cancer after Primary Taxane/ Platinum-Based Therapy. Ann Oncol. 2012;23. https://doi.org/10.1093/a nnonc/mds203.

6. Pujade-Lauraine E, Hilpert F, Weber B, et al. Bevacizumab Combined with Chemotherapy for Platinum-Resistant Recurrent Ovarian Cancer: The AURELIA Open-Label Randomized Phase III Trial. J Clin Oncol. 2014;32:13. https://doi.org/10.1200/JCO.2013.51.4489.

7. J. Prat and FIGO Committee on Gynecologic Oncology. FIGO's Staging Classification for Cancer of the Ovary, Fallopian Tube, and Peritoneum: Abridged Republication. J Gynecol Oncol. 2015;26:2. https://doi.org/10.3802/ jgo.2015.26.2.87. 
8. Solaß W, Alexander H, Nadiradze G, et al. Description of a Novel Approach for Intraperitoneal Drug Delivery and the Related Device. Surgical Endoscopy. 2012;26:1849-55. https://doi.org/10.1007/s00464-012-2148-0.

9. Solaß W, Herbette A, Schwartz T, et al. Therapeutic Approach of Human Peritoneal Carcinomatosis with Dbait in Combination with Capnoperitoneum: Proof of Concept. Surgical Endoscopy. 2012;26:3. https:// doi.org/10.1007/s00464-011-1964-y.

10. Blanco A, Giger-Parbst U, Solaß W, et al. Renal and Hepatic Toxicities after Pressurized Intraperitoneal Aerosol Chemotherapy (PIPAC). Ann Surgical Oncol. 2013;20:7. https://doi.org/10.1245/s10434-012-2840-2.

11. Tempfer CB, Celik I, Solaß W, et al. Activity of Pressurized Intraperitoneal Aerosol Chemotherapy (PIPAC) with Cisplatin and Doxorubicin in Women with Recurrent, Platinum-Resistant Ovarian Cancer: Preliminary Clinical Experience. Gynecol Oncol. 2014;132:2. https://doi.org/10.1016/j.ygyno.2 013.11.022.

12. Tempfer CB, Rezniczek GA, et al. Pressurized Intraperitoneal Aerosol Chemotherapy with Cisplatin and Doxorubicin in Women with Peritoneal Carcinomatosis: A Cohort Study. Anticancer Res. 2015;35:12. https://doi.org/1 0.1055/s-0035-1560004

13. Tempfer CB, Winnekendonk G, Solaß W, et al. Pressurized Intraperitoneal Aerosol Chemotherapy in Women with Recurrent Ovarian Cancer: A Phase 2 Study. Gynecologic Oncol. 2015;137:2. https://doi.org/10.1016/j.ygyno.201 5.02.009.

14. Hübner M, Grass F, Texeira-Farinha $H$, et al. Pressurized IntraPeritoneal Aerosol Chemotherapy - Practical Aspects. Eur J Surgical Oncol. 2017;43:6. https://doi.org/10.1016/j.ejso.2017.03.019.

15. Odendahl K, Solaß W, Demtröder C, et al. Quality of Life of Patients with End-Stage Peritoneal Metastasis Treated with Pressurized IntraPeritoneal Aerosol Chemotherapy (PIPAC). Eur J Surgical Oncol. 2015;41:10. https://doi. org/10.1016/j.ejso.2015.06.001.

16. Tempfer C, Giger-Pabst U, Hilal Z, et al. Pressurized Intraperitoneal Aerosol Chemotherapy (PIPAC) for Peritoneal Carcinomatosis: Systematic Review of Clinical and Experimental Evidence with Special Emphasis on Ovarian Cancer. Arch Gynecol Obstetrics. 2018;298:2. https://doi.org/10.1007/s00404018-4784-7.

17. Bakrin N, Tempfer C, Scambia G, et al. PIPAC-OV3: A Multicenter, OpenLabel, Randomized, Two-Arm Phase III Trial of the Effect on Progression-Free Survival of Cisplatin and Doxorubicin as Pressurized Intra-Peritoneal Aerosol Chemotherapy (PIPAC) vs. Chemotherapy Alone in Patients with PlatinumResistant Recurrent Epithelial Ovarian, Fallopian Tube or Primary Peritoneal Cancer. Pleura and Peritoneum. 2018;3:3. https://doi.org/10.1515/pp-20180114.

18. Alyami M, Hübner M, Grass F, et al. Pressurised Intraperitoneal Aerosol Chemotherapy: Rationale, Evidence, and Potential Indications. Lancet Oncol. 2019;20:e368-77. https://doi.org/10.1016/S1470-2045(19)30318-3.

19. Nowacki $M$, Alyami $M$, Villeneuve $L$, et al. Multicenter Comprehensive Methodological and Technical Analysis of 832 Pressurized Intraperitoneal Aerosol Chemotherapy (PIPAC) Interventions Performed in 349 Patients for Peritoneal Carcinomatosis Treatment: An International Survey Study'. Eur J Surgical Oncol. 2018;44:7. https://doi.org/10.1016/j.ejso.2018.02.014.

20. Karukstis KK, Thompson EH, Whiles JA, et al. Deciphering the Fluorescence Signature of Daunomycin and Doxorubicin. Biophysical Chem. 1998;73:3. https://doi.org/10.1200/JCO.2002.20.5.1248.

21. Zeger SL, Liang KY, Albert PS. Models for Longitudinal Data: A Generalized Estimating Equation Approach. Biometrics. 1988;44:4 https://pubmed.ncbi. nlm.nih.gov/3233245/.

22. Jacquet P, Sugarbaker PH. Clinical Research Methodologies in Diagnosis and Staging of Patients with Peritoneal Carcinomatosis. Cancer Treatment Res. 1996;82:359-74. https://doi.org/10.1007/978-1-4613-1247-5_23.

23. Khosrawipour V, Diaz-Carballo D, Acikelli AH, et al. Cytotoxic Effect of Different Treatment Parameters in Pressurized Intraperitoneal Aerosol Chemotherapy (PIPAC) on the in Vitro Proliferation of Human Colonic Cancer Cells. World J Surgical Oncol. 2017;15:43. https://doi.org/10.1186/s12 957-017-1109-4.

24. Khosrawipour V, Khosrawipour T, Kern AJP, et al. Distribution Pattern and Penetration Depth of Doxorubicin after Pressurized Intraperitoneal Aerosol Chemotherapy (PIPAC) in a Postmortem Swine Model. J Cancer Res Clin Oncol. 2016;142:11. https://doi.org/10.1007/s00432-016-2234-0.

25. Khosrawipour T, Schubert J, Khosrawipour V. Particle Stability and Structure on the Peritoneal Surface in Pressurized Intra-Peritoneal Aerosol Chemotherapy (PIPAC) Analysed by Electron Microscopy: First Evidence of a
New Physical Concept for PIPAC. Oncology Lett. 2019;17:6. https://doi.org/1 0.3892/ol.2019.10162.

26. Bellendorf A, Khosrawipour V, Khosrawipour T, et al. Scintigraphic Peritoneography Reveals a Non-Uniform 99mTc-Pertechnetat Aerosol Distribution Pattern for Pressurized Intra-Peritoneal Aerosol Chemotherapy (PIPAC) in a Swine Model. Surgical Endoscopy. 2018;32:1. https://doi.org/10.1 007/s00464-017-5652-4.

27. Kakchekeeva T, Demtröder C, Herath NI, et al. In Vivo Feasibility of Electrostatic Precipitation as an Adjunct to Pressurized Intraperitoneal Aerosol Chemotherapy (EPIPAC). Ann Surgical Oncol. 2016. https://doi.org/1 0.1245/s10434-016-5108-4.

28. Reymond M, Demtröder C, Solaß W, et al. Electrostatic Precipitation Pressurized IntraPeritoneal Aerosol Chemotherapy (EPIPAC): First in-Human Application. Pleura and Peritoneum. 2016;1:2. https://doi.org/10.1515/pp-201 6-0005.

\section{Publisher's Note}

Springer Nature remains neutral with regard to jurisdictional claims in published maps and institutional affiliations.

Ready to submit your research? Choose BMC and benefit from:

- fast, convenient online submission

- thorough peer review by experienced researchers in your field

- rapid publication on acceptance

- support for research data, including large and complex data types

- gold Open Access which fosters wider collaboration and increased citations

- maximum visibility for your research: over $100 \mathrm{M}$ website views per year

At BMC, research is always in progress.

Learn more biomedcentral.com/submissions 